\title{
The Impact of Teachers' Financial Compensation on their Job Satisfaction at Higher Secondary Level
}

Fozia Fatima* and Sabir Ali

Faculty of Higher Studies, National University of Modern Languages, Pakistan

*Corresponding author: Fozia Fatima, Faculty of Higher Studies National University of Modern Languages, H-9, Islamabad, Pakistan, Tel: 0333-5064632, E-mail: Islamabadfatimafozia@yahoo.com; dr_sabir@outlook.com

Rec date: Jan 06, 2016; Acc date: Apr 01, 2016; Pub date: Apr 06, 2016

Copyright: (C) 2016 Fatima F, et al. This is an open-access article distributed under the terms of the Creative Commons Attribution License, which permits unrestricted use, distribution, and reproduction in any medium, provided the original author and source are credited.

\begin{abstract}
This study was used to find the impact of teachers' financial compensation on their job satisfaction at higher secondary level in both public and private sectors of Islamabad. All the teachers of Higher Secondary level from private and public sector of Islamabad were randomly taken as sample. Total 30 teachers were conveniently taken as sample. A survey design was selected to be used in this study. The questionnaire which was used in this study consisted of three parts. The first part of questionnaire was about the demographic factors. The second part was about compensation practices which include 12 questions that were used to determine the direct and indirect financial compensation of the teachers at higher secondary level in Islamabad while third part covered the teachers' job satisfaction. The measurement of variables such as variety, autonomy, task identity and feedback which were collectively used to determine teachers' job satisfaction. The major findings of this study were that mostly higher secondary schools have fixed pay system while few have variable pay system. Teachers' salary does not link with their productivity while teachers agree that the attraction and retention of employee depend on the compensation. When teachers feel opportunities for recognition; decision power about their work; planning of task; their contribution to productivity; and especially when teachers receive helpful suggestion and guidance from their supervisor then they will be more satisfied. Similarly, the compensation practices and job satisfaction are highly correlated with each other but compensation practice in itself has no significant impact on the job satisfaction. Male and female teacher have no significant difference as well as there is no significant difference between public and private teachers who have different qualification and age groups in higher secondary of Islamabad while teachers who have different teaching experiences have significant difference towards job satisfaction.
\end{abstract}

Keywords: Financial compensation practice; Job satisfaction; Higher secondary teachers

\section{Introduction}

Money and financial benefits is important tool for enhancing organizational performance and sustained competitiveness because the key element for employment relationship and the single greatest operating cost for much organization is compensation. The payment for the work through which employees support their family and money is considered as the reward which is given to employees against work. The condition of satisfaction and dissatisfaction of employees depends on their salary because it is organizational responsibility to provide suitable financial rewards like salary to their employees because it has strong influence on employee motivation and retention [1]. All compensation factors include in employee pay and people do effort because they want some rewards in the term of money or promotion which was explained through expectancy theory [2]. Mostly employees expect that their pay and promotion will be increase when they work well in the workplace then this will cause increase in their job satisfaction level. Locke defined job satisfaction as "it is actually an enjoyable and exciting emotional condition which someone get in their work". The reduction of turnover rate and increase motivation of employees is directly linked with Job satisfaction. The pay, recognition and working environment identified in prior studies as different instrument for managing job satisfaction.
In educational system, the most essential part is teachers and 1.4 million teachers of Pakistan, who work across different levels of formal and non-formal delivery systems, in both public and private sectors are consider as social engineers of 21st century but their Economic status is seen as a critical measure to assess where teachers stand in the career options landscape in society especially in shifting perception of an overworked and underpaid profession. The remuneration paid to teachers at both the public and low cost private schools, is generally very low with hardly any job security because for years, teachers, especially those from the public sectors, have complaint of low remuneration and salary packages. Female teachers employed by low cost private schools are notoriously under paid. Lack of adequate salary package undermines teachers' productivity in several ways like resort to secondary employment activities and lead to increased absenteeism.

Statement of the Problem: Economic status of teachers is often cited as the driving engine for motivating teachers towards better performance and commitment. The basic focus of the study is "to find the impact of teachers' financial compensation on their job satisfaction at higher secondary level in both public and private sectors of Islamabad"

\section{Objectives}

The following are the main objectives of the study:

- To explore the financial compensation practices in both public and private sectors of Islamabad. 
- To investigate teachers' attitude towards job satisfaction

- To find a relationship among variety, autonomy, task identity and feedback for job satisfaction.

- To investigate the impact of financial compensation on teachers' job satisfaction.

- To analyze the effect of gender, organization, qualification, age and teaching experiences on the teachers' job satisfaction

\section{Review of related literature}

When employee looking for employment then the employee recruitment, retention, motivation, performance, feedback, satisfaction and overall business structure linked with their compensation. "Compensation packages can be considered total rewards systems, containing nonmonetary, direct, and indirect elements" [3]. There are different forms of compensation which are following;

Non-monetary compensation: "job that does not involve tangible value or any benefit an employee receives from an employer".

Direct compensation: "any performance-based pay that an employee receives or hourly wage or employee's base wage which can be an annual salary".

Indirect compensation: "far more varied, including everything from legally required public protection programs such as Social Security to health insurance, retirement programs, paid leave, child care or moving expenses" [3].

A compensation packages that are as individual as the employees who receive them by combining many of these compensation alternatives such as;

Base pay: "cash wage paid to the employee" [2].

Incentive pay: "a bonus paid when specified performance objectives are met".

Stock options: "a right to buy a piece of the business which may be given to an employee to reward excellent service" [3].

Bonuses: "a gift given occasionally to reward exceptional performance or for special occasions" [3].

Human for an organization is considering today as the most valuable asset so an organization should be properly administered him [4]. When employees feel inequality regarding pay difference between their profession and other profession then they got dissatisfied and disappointed with their own profession because their retention based on pay structure or compensation. Compensation acts as motivational factor for employee because "less pay as compared to work done is one of that extrinsic factor which is responsible for job dissatisfaction"[5]. The most important element in the organization is Job satisfaction because only that organization will be succeed in which their employees are more satisfied with their work environment and reward system. "When People are more satisfied then they will be more committed and more productive during their job because their satisfaction and dissatisfaction not only depend on the job but also depend upon employee's expectation about job" [6]. An actual job satisfaction is a combination of extrinsic and intrinsic motivation of the employees so the pay and working conditions, supervisor cooperation, communication style are all those external factors included in extrinsic job satisfaction while the responsibility or duties of the employees or the type of work that performed by the employees included in intrinsic job satisfaction. When employee satisfied from their work environment then they will perform well in workforce. All those elements or different facilities which are provided through organization such as good working condition, fairness in job, give promotion and rewards to employees produced job satisfaction among their employees [7].

The four core dimensions of job satisfaction which were determined through satisfaction survey such as Feedback, Autonomy, Variety, and Task Identity. So when deciding how to determine an employee's satisfaction in satisfaction survey, literature was useful that describe about it [8]. These four core dimensions of job satisfaction based on four questions those were designed to capture an employee's opinion on each of the core dimensions with the intent of compiling those responses such as the quantity and quality of job evaluation given to the employee by the owner or manager were consider as the Feedback questions and intrinsic evaluation of employees [9].

According to Lawler [9], "The job must allow a worker to feel personally responsible for a meaningful portion of his work." All those questions through which the authority and ownership of employees about their work that how the decide, plan, control and perform their tasks were included in the sense of Autonomy of employee [9]. Similarly, the third dimension of job satisfaction in employee which is known as Task Identity is defined as, "a very clear cycle of perceived closure and high visibility of the finished product [9].

The shape and formation of compensation practice depends on the leadership of Rational actors, or 'classicists' views as well as on the organizational behavior that influence on managerial choice about the compensation of employees [10]. The process of implementation depends on those compensation strategies and dictate path of action that were totally under the control of the managers. The management of any organization plays very important role in the decision making about compensation and the success of mission and survival of any organization directly linked with managerial actions or decisions because they act as the backbone of any organization [11]. The ability and freedom to choose the path of management is important through which they demonstrate and promotes employees' responsibilities and make specific code of conducts through which employee understand their basic tasks or duties. According to specific code of conducts employees perform their actions precisely in an organization [12]. A standard theory that is about the compensation determination that was not affected by the social, political and economic factors and according to rationalists; "compensation system choices are not driven by purely economic interests nor formulated through purely rational means [13]. The compensation process acts as "being the attraction, retention and motivation of valued talent and, most significantly, the means by which desirable employee behaviors might be induced. Moreover, they all deploy very similar compensation practices to achieve those ends in all organizations which subscribe to strategic compensation philosophically, equity ownership at a discounted rate is also a key element in the form of all employee share ownership programs, options (on a restricted basis) and stock purchase plans (SPP) [13]. A positive work environment, training and development, career opportunities include incentives, rewards and different forms of bonuses [13].

The government school teachers have a fixed salary package and pay scale and it usually starts from grade ninth up to fifteenth in government sector. "All School teachers having B.A/B.Sc./B.Ed qualification are placed in BS-16. Present metric and inter qualified teacher be given 4-6 years to enhance their qualification to qualify for higher pay" [14]. According to NEP (2009), every teacher in the country should be placed at sixteenth scale after 2010 and suggested to 
Page 3 of 11

renew the pay scale of teachers and this news related to up gradation of teachers published in Daily Jung [15].

The salaries of government school teachers included different allowances like; House allowance, medical allowance, conveyance allowance, compensatory allowance, adhoc and special allowance but the quantity of these allowances is very low and near about just 4000-9000 Pak rupees in the pay of teachers. A lot of deduction has been carried out from the pay of teachers such as deductions from their pays are on the name of G.P. fund and benevolent fund. The government of Pakistan does not show any interest in the practical implementation of valid compensation practices for teachers. This condition is very severe in non-governmental sector where there is no concept of any fund and no security after retirement. The objective of the present study is to measure and compare the impact of financial compensation on the teachers' job satisfaction.

\section{Methodology}

Population and sample of study: All the teachers of Higher Secondary level from private and public sector of Islamabad were randomly taken as sample. Total 30 teachers were conveniently taken as sample. A survey design was used in this study.

Instrumentation: The questionnaire which was used in this study consisted of three parts. The first part of questionnaire was about the demographic factors. The second part was about compensation practices which include 12 questions that were used to determine the direct and indirect financial compensation of the teachers at higher secondary level in Islamabad while third part covered the teachers' job satisfaction. The measurement of variables such as variety, autonomy, task identity and feedback which were collectively used to determine teachers' job satisfaction. This questionnaire was developed after a thorough study of literature. Teachers responded to the items on five point Likert scale ranging from "strongly disagree" to "strongly agree".

\section{Data Analysis Procedures}

The SPSS used to analyze the survey results. The researcher used two statistical analysis phases on the data. Descriptive statistics were used to determine such as frequencies, percentages, and standard deviation. Independent t-tests were computed to compare gender. Pearson correlations were computed to show relationships. Multiple regressions was used to compute the relationship between compensation practices and teachers' job satisfaction. ANOVA test applied to discover if there were statistically significant differences among teachers with different backgrounds, education and teaching experiences.

\section{Results}

The main focus of this study is to find the impact of teachers' financial compensation on their job satisfaction at higher secondary level in both public and private sectors of Islamabad. Data was collected through questionnaire and organized on SPSS and then result presented into tabular forms. There were following main results which are presented here.

\begin{tabular}{|c|c|c|c|c|c|}
\hline No & Compensation practice & CNS & Yes & No & Mean \\
\hline 1 & Does the Organization have? & $\%$ & $\%$ & $\%$ & \\
\hline A & Fixed pay system & 0.00 & 73.5 & 14.7 & 1.17 \\
\hline $\mathrm{B}$ & Variable pay system & 0.00 & 2.9 & 85.3 & 1.97 \\
\hline 2 & \multicolumn{5}{|l|}{ What are the components of your base salary? } \\
\hline A & DA & 0.00 & 29.4 & 55.9 & 1.66 \\
\hline B & HRA & 0.00 & 70.6 & 17.6 & 1.20 \\
\hline $\mathrm{C}$ & PF & 0.00 & 23.5 & 44.1 & 1.27 \\
\hline $\mathrm{D}$ & ESI & 0.00 & 0.00 & 8.3 & 0.20 \\
\hline $\mathrm{E}$ & Gratuity & 0.00 & 32.4 & 20.6 & 0.83 \\
\hline $\mathrm{F}$ & Medical Allowance & 0.00 & 88.2 & 0.00 & 1.00 \\
\hline G & Conveyance Allowance & 0.00 & 35.3 & 41.2 & 1.33 \\
\hline $\mathrm{H}$ & LTA & 0.00 & 8.8 & 23.5 & 0.63 \\
\hline 3 & \multicolumn{5}{|l|}{ What is the ratio of fixed and variable pay in your company? } \\
\hline A & $60 \%-40 \%$ & 17.6 & 67.6 & 2.9 & 0.83 \\
\hline B & $70 \%-30 \%$ & 0.00 & 0.00 & 0.00 & 0.00 \\
\hline $\mathrm{C}$ & $80 \%-20 \%$ & 0.00 & 0.00 & 0.00 & 0.00 \\
\hline $\mathrm{D}$ & $75 \%-25 \%$ & 0.00 & 0.00 & 0.00 & 0.00 \\
\hline 4. & \multicolumn{5}{|l|}{ What is your monthly salary not including bonus? } \\
\hline
\end{tabular}


Citation: Fatima F, Ali S (2016) The Impact of Teachers' Financial Compensation on their Job Satisfaction at Higher Secondary Level. J

\begin{tabular}{|c|c|c|c|c|c|}
\hline A & Less than 10,000 & 0.00 & 88.2 & 0.00 & 1.00 \\
\hline B & $10,000-20,000$ & 0.00 & 0.00 & 0.00 & 0.00 \\
\hline C & $20,000-30,000$ & 0.00 & 0.00 & 0.00 & 0.00 \\
\hline $\mathrm{D}$ & 30,000 and above & 0.00 & 0.00 & 0.00 & 0.00 \\
\hline 5 & In addition to your base salary do you regularly receive cash bonuses? & 0.00 & 0.00 & 88.2 & 2.00 \\
\hline$A$ & Annual/Year bonus & 0.00 & 88.2 & 0.00 & 1.00 \\
\hline B & Incentive Bonus & 0.00 & 0.00 & 0.00 & 0.00 \\
\hline 7 & \multicolumn{5}{|l|}{ What kind of non-cash benefits do you receive? } \\
\hline A & Housing & 0.00 & 44.1 & 44.1 & 1.5 \\
\hline B & Medi claim & 0.00 & 44.1 & 44.1 & 1.5 \\
\hline C & Retirement benefits & 0.00 & 50.0 & 38.0 & 1.43 \\
\hline $\mathrm{D}$ & Day Care & 17.6 & 29.4 & 41.2 & 1.27 \\
\hline $\mathrm{E}$ & Education reimbursement & 0.00 & 44.1 & 44.1 & 1.5 \\
\hline $\mathrm{F}$ & Sick leave & 0.00 & 47.1 & 41.2 & 1.47 \\
\hline G & Cell phone & 0.00 & 0.00 & 88.2 & 2.00 \\
\hline $\mathrm{H}$ & Laptops & 0.00 & 0.00 & 88.2 & 2.00 \\
\hline 1 & Social security & 88.2 & 0.00 & 0.00 & 0.00 \\
\hline $\mathrm{J}$ & Insurance & 0.00 & 55.9 & 32.4 & 1.37 \\
\hline $\mathrm{K}$ & Private use of official vehicles & 0.00 & 26.5 & 61.8 & 1.70 \\
\hline $\mathrm{L}$ & Foods & 0.00 & 0.00 & 88.2 & 2.00 \\
\hline M & Loan & 0.00 & 0.00 & 88.2 & 2.00 \\
\hline $\mathrm{N}$ & Uniform & 0.00 & 20.6 & 67.6 & 1.77 \\
\hline $\mathrm{O}$ & Festival bonus & 0.00 & 0.00 & 88.2 & 2.00 \\
\hline $\mathrm{P}$ & Vocation pay & 0.00 & 58.8 & 29.4 & 1.33 \\
\hline 8 & $\begin{array}{l}\text { Does your organization give a general increase in compensation in a year? If yes, by what } \\
\%\end{array}$ & 0.00 & 88.2 & 0.00 & 1.00 \\
\hline A & $5 \%-7 \%$ & 0.00 & 50.0 & 38.2 & 1.43 \\
\hline B & $7 \%-9 \%$ & 0.00 & 52.9 & 35.2 & 1.40 \\
\hline C & $9 \%-11 \%$ & 0.00 & 14.7 & 73.5 & 1.83 \\
\hline 9 & Does your organization have performance appraisal system? & 2.90 & 85.3 & 0.00 & 0.97 \\
\hline 10 & \multicolumn{5}{|l|}{ In your organization employee are considered for reward and recognition mostly for; } \\
\hline A & Innovative and creative & 88.2 & 0.00 & 0.00 & 0.00 \\
\hline B & Increased productivity/results/outcome & 88.2 & 0.00 & 0.00 & 0.00 \\
\hline C & Customer satisfaction & 88.2 & 0.00 & 0.00 & 0.00 \\
\hline D & All of above & 88.2 & 0.00 & 0.00 & 0.00 \\
\hline 11 & Does your organization link your salary with your productivity? & 0.00 & 0.00 & 88.2 & 2.00 \\
\hline 12 & Does the compensation paid by your company attract and retain the employees? & 0.00 & 88.2 & 0.00 & 1.00 \\
\hline
\end{tabular}


Citation: Fatima F, Ali S (2016) The Impact of Teachers' Financial Compensation on their Job Satisfaction at Higher Secondary Level. J

Page 5 of 11

Note: Can't Say $(\mathrm{CNS})=(0)$, Yes $=(1), \mathrm{No}=(2)$

Table 1: Percentage of teachers' responses towards compensation practices.

Table 1 shows compensation practices in the form of percentage and mean values. Compensation practice such as organizations has $73.5 \%$ fixed pay system while $14.7 \%$ organization has variable pay system. The basic pay of the teachers contain following components such as defense allowance (DA) which was found 29.4\%; house rent allowance(HRA) which was found $70.6 \%$; medical allowance which was found $88.2 \%$ : gratuity which was found $32.4 \%$; PA which was found 23.55 and conveyance allowance which was $35.5 \%$. The ratio $60 \%-40 \%$ of fixed and variable pay which was found $67.6 \%$ was common in the organization. The monthly salary including less than 10,000 bonuses which was found $88.2 \%$ in the organization. $88.2 \%$ teachers receive cash bonuses in addition to their base salary mostly in the form of annual/year-end bonus which was found to be $88.2 \%$. The non-cash benefits such as housing (44.1\%), medical (44.1\%), retirement benefits $(50 \%)$, day care $(29.4 \%)$, education reimbursement (44.1\%), sick leave (47.1), and vocation pay $(58.8 \%)$ common in the compensation of teachers while cellphone $(88.2 \%)$, laptops $(88.2 \%)$, insurance(55.9\%), private use of official vehicle(61.8\%), food (88.2\%), loan $(88.2 \%)$, uniform (67.6) and festival bonus (88.2\%) were not found in the compensation of the teachers. $88.2 \%$ teachers have no idea about the social security that's why the select "can't say" about the social security as a non-cash benefits. $88.2 \%$ teachers accept that they receive a general increase in their compensation in a year and its percentage such as $5 \%-7 \%$ which was found to be $50 \%$ and $7 \%-9 \%$ which was found to be $52.9 \%$ was common. This table also shows that $85.3 \%$ teachers accept that their organization have performance appraisal system. 88.2\% teacher selected "can't say" about when researcher asked about the consideration of reward and recognition which were based on their innovative and creative, increased productivity/result/ outcome and customer satisfaction. $88.2 \%$ teachers said that their salary does not link with their productivity while $88.2 \%$ teachers agree that the attraction and retention of employee depend on the compensation (Table 2).

\begin{tabular}{|c|c|c|c|c|c|c|c|}
\hline No & Job Satisfaction & SDA & DA & UD & A & SA & M \\
\hline 1 & My job has variety. & 2.9 & 0.0 & 0.0 & 47.1 & 38.2 & 4.33 \\
\hline 2 & My job challenges me. & 0.0 & 0.0 & 2.9 & 41.2 & 44.1 & 4.47 \\
\hline 3 & My job is not repetitive. & 0.0 & 0.0 & 0.0 & 44.1 & 44.1 & 4.50 \\
\hline 4 & There are opportunities for recognition in my job. & 0.0 & 2.9 & 0.0 & 32.4 & 52.9 & 4.53 \\
\hline 5 & I plan my own work. & 0.0 & 2.9 & 0.0 & 38.2 & 47.1 & 4.47 \\
\hline 6 & I can see the beginning, middle, and end of my tasks. & 0.0 & 0.0 & 2.9 & 61.8 & 23.5 & 4.23 \\
\hline 7 & I decide how my work should be done. & 0.0 & 0.0 & 0.0 & 64.7 & 23.5 & 4.27 \\
\hline 8 & I use many different skills in my job & 0.0 & 5.9 & 0.0 & 38.2 & 44.1 & 4.37 \\
\hline 9 & I feel personally responsible for my work. & 0.0 & 0.0 & 0.0 & 44.1 & 44.1 & 4.50 \\
\hline 10 & I have opportunities to implement my own ideas in my work. & 0.0 & 2.9 & 0.0 & 44.1 & 41.2 & 4.40 \\
\hline 11 & My work contributes to the success of the business. & 2.9 & 0.0 & 2.9 & 52.9 & 29.4 & 4.20 \\
\hline 12 & The things I do for my job are significant. & 0.0 & 0.0 & 11.8 & 55.9 & 20.6 & 4.10 \\
\hline 13 & I have access to information on key performance measures related to my job. & 0.0 & 2.9 & 5.9 & 35.3 & 44.1 & 4.37 \\
\hline 14 & My job offers opportunities to increase my skills or knowledge. & 0.0 & 2.9 & 5.9 & 29.4 & 50.0 & 4.43 \\
\hline 15 & My supervisor makes helpful suggestions. & 0.0 & 5.9 & 0.0 & 79.4 & 0.0 & 3.90 \\
\hline 16 & My superior tells me how I am doing. & 0.0 & 2.9 & 2.9 & 73.5 & 8.8 & 4.00 \\
\hline 17 & My job offers opportunities to increase my skills or knowledge. & 0.0 & 0.0 & 0.0 & 41.2 & 47.1 & 4.50 \\
\hline
\end{tabular}

Table 2: Percentage of teachers' responses towards job satisfaction.

Table 2 shows teachers' responses towards their job satisfaction. This table shows that when teachers feel opportunities for recognition which was found to be $52.9 \%$; decision power about their work which was found to be $64.7 \%$; planning of task which was found to be $61.8 \%$; their contribution to success which was found to be $52.9 \%$; significance of task which was found to be $55.9 \%$; and specially when teachers 
Citation: Fatima F, Ali S (2016) The Impact of Teachers' Financial Compensation on their Job Satisfaction at Higher Secondary Level. J

receive helpful suggestion which was found to be $79.4 \%$ and guidance from their supervisor then they will be more satisfied from their job (Table 3).

\begin{tabular}{|l|l|l|l|l|l|}
\hline Variables & Variety & Autonomy & Task Identity & Feedback \\
\hline Variety & 1 & $0.581^{* *}$ & 0.319 & 0.110 \\
\hline Autonomy & $0.581^{* *}$ & 1 & $0.412^{*}$ & 0.170 \\
\hline Task Identity & 0.319 & $0.412^{*}$ & 1 & $0.651^{* *}$ \\
\hline Feedback & 0.110 & 0.170 & $0.657^{* *}$ & 1 & $0.839^{\star *}$ \\
\hline Job Satisfaction & $0.681^{* *}$ & $0.755^{* *}$ & $0.839^{* *}$ & $0.634^{* *}$ & 1 \\
\hline
\end{tabular}

Table 3: Correlations among variety, autonomy, task identity, feedback and job satisfaction.

Table 3 show a correlation among variety, autonomy, task identity, feedback and job satisfaction in which variety and autonomy which was found to be $0581^{\star *}$; variety and task identity which was found to be 0.319 ; variety and feedback which was found to be 0.110 and variety and job satisfaction which was found to be $0.681^{\star}$; autonomy and task identity which was found to be $0.412^{*}$; autonomy and feedback which was found to be 0.170 and autonomy and job satisfaction which was found to be $0.755^{* *}$; task identity and feedback which was found to be $0.657^{* *}$; task identity and job satisfaction which was found to be $0.839^{* *}$ and feedback and job satisfaction which was found to be $0.634^{* *}$, all of these variable are significant at the 0.05 level (2-tailed) of confidence. It means there is positive correlation among variety, autonomy, task identity, and feedback and job satisfaction.

\begin{tabular}{|l|l|l|l|l|}
\hline Model & $\mathbf{R}$ & $\mathbf{R}$ Square & Adjusted R Square & Std. Error of the Estimate \\
\hline 1 & $0.918 a$ & 0.842 & 0.367 & 3.929 \\
\hline $\begin{array}{l}\text { a. Predictors: (Constant), performance appraisal, VPS, ESI, Gratuity, insurance, LTA, DA, education reimbursement, private use of official vehicle, fixed pay system, } \\
\text { RATIO.1, PF, CA, medical, uniform, HRA, day care, housing, vacation pay, retirement benefits, sick leave. }\end{array}$ \\
\hline
\end{tabular}

Table 4a: Multiple linear regressions for compensation practices and job satisfaction.

Table 4a shows that compensation practice and job satisfaction have strong impact on each other's because the $\mathrm{R}$ value which is 0.918 shows that compensation practices and job satisfaction are highly correlated.

\begin{tabular}{|c|c|c|c|c|c|c|}
\hline \multicolumn{2}{|c|}{ Model } & \multirow{2}{*}{$\begin{array}{l}\text { Sum of Squares } \\
575.126\end{array}$} & \multirow{2}{*}{$\begin{array}{l}\mathbf{d f} \\
21\end{array}$} & \multirow{2}{*}{$\begin{array}{l}\text { Mean Square } \\
27.387\end{array}$} & \multirow{2}{*}{$\begin{array}{l}\mathbf{F} \\
1.774\end{array}$} & \multirow{2}{*}{$\begin{array}{l}\text { Sig. } \\
0.223 b\end{array}$} \\
\hline 1 & Regression & & & & & \\
\hline & Residual & 108.046 & 7 & 15.435 & & \\
\hline & Total & 683.172 & 28 & & & \\
\hline
\end{tabular}

Table 4b: ANVOA of multiple linear regression for compensation practices and job satisfaction.

Table $4 \mathrm{~b}$ shows that the difference between the compensation practices and job satisfaction of teachers is not significant.

\begin{tabular}{|l|l|l|l|l|l|l|l|}
\hline Variables & Genders & N & Means & Std. Dev. & Std. Error & df \\
\hline \multirow{2}{*}{ Job Satisfaction } & Male & 13 & 73.23 & 6.139 & 1.703 & 28 \\
\cline { 2 - 7 } & Female & 17 & 73.88 & 3.789 & 0.723 & -0.358 \\
\hline
\end{tabular}

Table 5: N, Mean, SD and t test of job satisfaction of both male and female teachers. 
Citation: Fatima F, Ali S (2016) The Impact of Teachers' Financial Compensation on their Job Satisfaction at Higher Secondary Level. J

Page 7 of 11

Table 5 shows the means of teachers' attitude towards job satisfaction at higher secondary level in Islamabad. The mean of female i.e. 73.88 is greater than the mean of male teachers i.e. 73.23 and the difference in means was not found to be significant. So male and female teachers have no difference regarding job satisfaction in their respective organizations.

\begin{tabular}{|l|l|l|l|l|l|l|l|l|}
\hline Variables & Organization & N & Means & Std. Dev. & Std. Error & T & df & Sig. \\
\hline \multirow{2}{*}{ Job Satisfaction } & Public & 13 & 73.31 & 3.093 & 0.858 & -0.283 & 28 & 0.779 \\
\cline { 2 - 9 } & Private & 17 & 73.82 & 5.961 & 1.446 & & & \\
\hline
\end{tabular}

Table 6: N, Mean, SD and test of job satisfaction of both public and private teachers.

Table 6 shows the means of public and private teachers' attitude towards job satisfaction at higher secondary level in Islamabad. The mean of private teachers i.e. 73.82 is greater than the mean of public teachers i.e. 73.31 and the difference in means was not found to be significant. So public and private teachers have no difference regarding job satisfaction.

\begin{tabular}{|l|l|l|l|l|}
\hline Qualification & N & Mean & Std. Deviation & Std. Error \\
\hline Masters & 20 & 73.20 & 4.652 & 1.040 \\
\hline MPhil & 6 & 75.33 & 3.386 & 1.382 \\
\hline PhD & 4 & 73.00 & 8.042 & 4.021 \\
\hline Total & 30 & 73.60 & 4.861 & 0.887 \\
\hline
\end{tabular}

Table 7.1: N, Means, Standard deviation, Standard Error of different qualification groups.

Table 7.1 shows a mean difference of different qualification group in which master which was found to be 73.20; MPhil which was found to be 75.33 and $\mathrm{PhD}$ which was found to be 73.00 . There is no significant difference among qualification groups towards job satisfaction.

\begin{tabular}{|l|l|l|l|l|}
\hline Qualification & Sum of Squares & df & Mean Square & Sig. \\
\hline Between groups & 22.667 & 2 & 11.333 & 0.635 \\
\hline Within groups & 662.533 & 27 & 24.538 & 0.462 \\
\hline Total & 685.200 & 29 & & \\
\hline
\end{tabular}

Table 7.2: ANVOA for teachers' job satisfaction and their different qualification groups.

Table 7.2 shows the mean difference between the qualification groups which was found to be 22.667 and within the qualification groups which was found to be 662.533 . There is a difference between and within the qualification groups about the job satisfaction but this difference is not significant.

\begin{tabular}{|l|l|l|l|l|}
\hline \multirow{2}{*}{ (I) qualification } & (J) qualification & Mean Difference (I-J) & Std. Error & Sig. \\
\hline \multirow{2}{*}{ MPhil } & MPhil & -2.133 & 2.306 & 0.363 \\
\cline { 2 - 5 } & PhD & 0.200 & 2.713 & 0.942 \\
\hline PhD & Masters & 2.133 & 2.306 & 0.363 \\
\cline { 2 - 5 } & PhD & 2.333 & 3.198 & 0.472 \\
\hline & Masters & -0.200 & 2.713 & 0.942 \\
\cline { 2 - 5 } & MPhil & -2.333 & 3.198 & 0.472 \\
\hline
\end{tabular}

Table 7.3: Post Hoc (LSD) test for multiple comparison of qualification group.

Table 7.3 show a post hoc test for means difference between teachers' job satisfaction and their qualifications (Masters, MPhil and $\mathrm{PhD})$. There is statistically not significant difference between the masters and MPhil group which was found to be -2.133 and MPhil and $\mathrm{PhD}$ groups of teachers which was found to be 2.333 and $\mathrm{PhD}$ and masters which was found to be 0.200 at 0.05 level of significance. So 
Citation: Fatima F, Ali S (2016) The Impact of Teachers' Financial Compensation on their Job Satisfaction at Higher Secondary Level. J

there is no significant mean difference in teachers' job satisfaction on the basis of their qualification groups.

\begin{tabular}{|l|l|l|l|l|}
\hline Age & N & Mean & Std. Deviation & Std. Error \\
\hline $25-30$ & 3 & 67.00 & 10.392 & 6.000 \\
\hline $31-35$ & 5 & 75.00 & 8.000 & 3.578 \\
\hline $36-40$ & 10 & 74.50 & 2.068 & 0.654 \\
\hline 41 -above & 12 & 73.92 & 1.505 & 0.434 \\
\hline Total & 30 & 73.60 & 4.861 & 0.887 \\
\hline
\end{tabular}

Table 8.1: N, Means, Std. deviation, and Standard Error of different age groups.

Table 8.1 shows the means of different age groups in which the mean of (25-30) age group which was found to be 67.00, (31-35) age group which was found to be $75.00,(36-40)$ age group which was found to be 74.50 and (41-above) age group which was found to be 73.92. So there is no significant difference on the basis of age groups about job satisfaction except the 25-30 age group.

\begin{tabular}{|l|l|l|l|l|l|}
\hline Age & Sum of Squares & df & Mean Square & F & Sig. \\
\hline Between groups & 149.783 & 3 & 49.928 & 2.425 & 0.088 \\
\hline Within groups & 535.417 & 26 & 20.593 & & \\
\hline Total & 685.200 & 29 & & & \\
\hline
\end{tabular}

Table 8.2: ANVOA for teachers' job satisfaction and their different age groups.

Table 8.2 shows the mean difference between the age groups which was found to be 149.783 and within the age groups which was found to be 535.417. There is a difference between and within the age groups about the job satisfaction but this difference is not significant.

\begin{tabular}{|l|l|l|l|l|}
\hline \multirow{3}{*}{ (I) age } & (J) age & Mean Difference (I-J) & Std. Error & Sig. \\
\hline & $31-35$ & $-8.000^{*}$ & 3.314 & 0.023 \\
\cline { 2 - 5 } & $36-40$ & $-7.500^{*}$ & 2.987 & 0.019 \\
\cline { 2 - 5 } & 41 -above & $-6.917^{*}$ & 2.929 & 0.026 \\
\hline $31-35$ & $25-30$ & $8.000^{*}$ & 3.314 & 0.023 \\
\cline { 2 - 5 } & $36-40$ & 0.500 & 2.486 & 0.842 \\
\cline { 2 - 5 } $36-40$ & 41 -above & 1.083 & 2.416 & 0.658 \\
\hline \multirow{5}{*}{41 -above } & $25-30$ & $7.500^{*}$ & 2.987 & 0.019 \\
\cline { 2 - 5 } & $31-35$ & -0.0500 & 2.486 & 0.842 \\
\cline { 2 - 5 } & $41-$-above & 0.583 & 1.943 & 0.766 \\
\hline & $25-30$ & $6.917^{*}$ & 2.929 & 0.026 \\
\cline { 2 - 5 } & $31-35$ & -1.083 & 2.416 & 0.658 \\
\cline { 2 - 5 } & $36-40$ & -0.583 & 1.943 & 0.766 \\
\hline
\end{tabular}

Table 8.3: Post Hoc (LSD) test for multiple comparison of age group.

Table 8.3 shows a post hoc test for means difference between teachers' job satisfaction and their different age groups (25-30, 31-35, 36-40 and 41-above). There is no statistically difference among teachers' job satisfaction who belongs to 25-30 and 31-35 which was found to be $-8.000,25-30$ and $36-40$ which was found to be -7.500 and 25-30 and 41-above which was found to be -6.917 at 0.05 level of confidence. So there is no significant mean difference in teachers' job satisfaction on the basis of their age groups. 
Citation: Fatima F, Ali S (2016) The Impact of Teachers' Financial Compensation on their Job Satisfaction at Higher Secondary Level. J

\begin{tabular}{|l|l|l|l|l|}
\hline Teaching Experiences & N & Mean & Std. Deviation & Std. Error \\
\hline $1-5$ & 4 & 65.75 & 7.890 & 3.945 \\
\hline $6-10$ & 6 & 74.33 & 4.033 & 1.647 \\
\hline $11-15$ & 8 & 76.25 & 3.284 & 1.161 \\
\hline $16-$ above & 12 & 74.08 & 1.730 & 0.499 \\
\hline Total & 30 & 73.60 & 4.861 & 0.887 \\
\hline
\end{tabular}

Table 9.1: N, Means, Std.deviation, Standard Error of different teaching experience groups.

Table 9.1 shows the means of different teaching experience (1-5 and 6-10, 11-15 and 16 above) years in which the teaching experience (1-5) years which was found to be 65.75 , teaching experience (6-10) years was found to be 74.33 , teaching experience (11-15) years was found to be 76.25 and teaching experience (16-above) years which was found to be 74.08. Therefore the higher teaching experienced groups have more significant means differences than lower teaching experienced groups about job satisfaction.

\begin{tabular}{|l|l|l|l|l|l|}
\hline Teaching Experience & Sum of Squares & Df & Mean Square & F & Sig. \\
\hline Between groups & 308.700 & 3 & 102.900 & 7.106 & 0.001 \\
\hline Within groups & 376.500 & 26 & 14.481 & & \\
\hline Total & 685.200 & 29 & & & \\
\hline
\end{tabular}

Table 9.2: ANVOA for teachers' job satisfaction and their different teaching experience groups.

Table 9.2 shows the mean difference between the teaching experience groups which was found to be 308.700 and within the teaching experiences groups which was found to be 376.500 . There is significant difference between and within the teaching experiences groups about the job satisfaction.

\begin{tabular}{|c|c|c|c|c|}
\hline (I) Teaching Experience & (J) Teaching Experience & Mean Difference (I-J) & Std. Error & Sig. \\
\hline \multirow[t]{3}{*}{$1-5$} & $6-10$ & $-8.583^{*}$ & 2.456 & 0.002 \\
\hline & $11-15$ & $-10.500^{*}$ & 2.330 & 0.000 \\
\hline & 16-above & $-8.333^{*}$ & 2.197 & 0.001 \\
\hline \multirow[t]{3}{*}{$6-10$} & $1-5$ & $8.583^{*}$ & 2.456 & 0.002 \\
\hline & $11-15$ & -1.917 & 2.055 & 0.360 \\
\hline & 16-above & 0.250 & 1.903 & 0.896 \\
\hline \multirow[t]{3}{*}{$11-15$} & $1-5$ & $10.500^{*}$ & 2.330 & 0.000 \\
\hline & $6-10$ & 1.917 & 2.055 & 0.360 \\
\hline & 16-above & 2.167 & 1.737 & 0.223 \\
\hline \multirow[t]{3}{*}{ 16-above } & $1-5$ & $8.333^{*}$ & 2.197 & 0.001 \\
\hline & $6-10$ & -0.250 & 1.903 & 0.896 \\
\hline & $11-15$ & -2.167 & 1.737 & 0.223 \\
\hline
\end{tabular}

Table 9.3: Post Hoc (LSD) test for multiple comparison of teaching experience group.

Table 9.3 show a post hoc test for means difference between teachers' job satisfaction and their different teaching experiences. The mean difference among 1-5 and 6-10 years of teaching experience which was found to be $-8.583,1-5$ and $11-15$ which was found to be
-10.500 and $1-5$ and 16 -above which was found to be -8.333 . This shows that there is a statistically difference among the teachers' job satisfaction who have $1-5,6-10,11-15$ and 16 above years teaching experiences at 0.05 level of confidence. So there is significant mean 
difference in teachers' job satisfaction on the basis of their teaching experience groups because the higher teaching experienced groups have more significant means differences than lower teaching experienced groups.

\section{Findings}

There are following main finding of this study;

Compensation practice such as organizations has $73.5 \%$ fixed pay system while $14.7 \%$ organization has variable pay system. The noncash benefits such as housing (44.1\%), medical (44.1\%), retirement benefits (50\%), daycare (29.4\%), education reimbursement $(44.1 \%)$, sick leave (47.1), and vocation pay $(58.8 \%)$ common in the compensation of teachers while cellphone(88.2\%), laptops $(88.2 \%)$, insurance(55.9\%), private use of official vehicle(61.8\%), food $(88.2 \%)$, loan $(88.2 \%)$, uniform (67.6) and festival bonus (88.2\%) were not found in the compensation of the teachers. $88.2 \%$ teachers said that their salary does not linked with their productivity while $88.2 \%$ teachers agree that the attraction and retention of employee depend on the compensation.

- The teachers who receive helpful suggestion which was found to be $79.4 \%$ and guidance from their supervisor then they will be more satisfied from their job.

- There is a positive correlation among variety, autonomy, task identity, and feedback and job satisfaction.

- Male and female teachers have no difference regarding job satisfaction in their respective organizations.

- Public and private teachers have no difference regarding their job satisfaction.

Qualification group in which master which was found to be 73.20 ; MPhil which was found to be 75.33 and $\mathrm{PhD}$ which was found to be 73.00.The mean difference between the qualification groups which was found to be 22.667 and within the qualification groups which was found to be 662.533. A post hoc test for means difference between teachers' job satisfaction and their qualifications (Masters, MPhil and $\mathrm{PhD}$ ). There is statistically not significant difference between the master and MPhil group which was found to be -2.133 and MPhil and $\mathrm{PhD}$ groups of teachers which was found to be 2.333 and $\mathrm{PhD}$ and masters which was found to be 0.200 .

The means of different age groups in which the mean of (25-30) age group which was found to be $67.00,(31-35)$ age group which was found to be $75.00,(36-40)$ age group which was found to be 74.50 and (41-above) age group which was found to be 73.92 . The mean difference between the age groups which was found to be 149.783 and within the age groups which was found to be 535.417. There is no statistically difference among teachers' job satisfaction that belongs to 25-30 and 31-35 which was found to be $-8.000,25-30$ and 36-40 which was found to be -7.500 and $25-30$ and 41 -above which was found to be -6.917 .

The means of different teaching experience (1-5 and 6-10, 11-15 and 16 above) years in which the teaching experience (1-5) years which was found to be 65.75 , teaching experience (6-10) years was found to be 74.33, teaching experience (11-15) years was found to be 76.25 and teaching experience (16-above) years which was found to be 74.08 . The mean difference between the teaching experience groups which was found to be 308.700 and within the teaching experiences groups which was found to be 376.500. The mean difference among 1-5 and 6-10 years of teaching experience which was found to be $-8.583,1-5$ and
11-15 which was found to be -10.500 and 1-5 and 16-above which was found to be -8.333 . This shows that there is a statistically difference among the teachers' job satisfaction who have 1-5, 6-10, 11-15 and 16 above years teaching experiences at 0.05 level of confidence.

\section{Discussion}

This study was basically focus on five objectives such as to explore the financial compensation practices in both public and private sectors of Islamabad; to investigate teachers' attitude towards job satisfaction; o find a relationship among variety, autonomy, task identity and feedback for job satisfaction; to investigate the impact of financial compensation on teachers' job satisfaction and to analyze the effect of gender, organization, qualification, age and teaching experiences on the teachers' job satisfaction at higher secondary level.

Mostly higher secondary schools have fixed pay system while few have variable pay system because all the mandatory and nonmandatory benefits are little bit different at organization level and employers provide most benefits voluntarily but the law requires. Others. The basic pay of the teachers contain six main components such as defense allowance (DA); house rent allowance(HRA), medical allowance, gratuity, PA and conveyance allowance because most organization recognize that they have a responsibility to provide health, safety, security and general welfare to their employees. The monthly salary of teachers including less than 10,000 bonus and teachers receive cash bonuses in addition to their base salary mostly in the form of annual/year-end bonus. The non-cash benefits such as housing, medical, retirement benefits, day care, education reimbursement, sick leaves and vocation pay common in the compensation of teachers while cell phone, laptops, insurance, private use of official vehicle, food, loan, uniform and festival bonus were not found in the compensation of the teachers. Teachers have no idea about the social security because this concept is not too much highlighted in the form of compensation. Teachers accept that they receive a general increase in their compensation in a year and its percentage such as $5 \%-7 \%$ and $7 \%-9 \%$ which were common and it is too much little increase in the pay of teachers that's why lack of adequate salary package undermines teachers' productivity and unfortunately their reward and recognition which were not based on their innovative and creative, increased productivity/result/outcome and customer satisfaction because their salary does not linked with their productivity while teachers agree that the attraction and retention of employee depend on the compensation because not enough money in the form of salary resort to secondary employment activities among the teachers which reduced their motivation towards their teaching.

When teachers feel opportunities for recognition; decision power about their work; planning of task; their contribution to productivity; and especially when teachers receive helpful suggestion and guidance from their supervisor then they will be more satisfied towards their job because the job description and job specification is very important role in the job satisfaction of the employees. The job characteristics such as variety, autonomy, and task identity and feedback system are highly correlated with each other's because according to job characteristic theory, employees experience intrinsic compensation and create the potential for increased performance and higher employee satisfaction. The compensation practices and job satisfaction are highly correlated with each other but compensation practice in itself has no significant impact on the job satisfaction because job itself can be very powerful factor in the compensation equation. The job itself is a central issue in 
Citation: Fatima F, Ali S (2016) The Impact of Teachers' Financial Compensation on their Job Satisfaction at Higher Secondary Level. J

Page 11 of 11

many theories of motivation and a long way in explaining the importance of the job itself in determining compensation.

The mean difference of gender, organization, qualification, age and teaching experience group about job satisfaction shows that male and female teacher have no significant difference as well as there is no significant difference between public and private teachers who have different qualification and age groups because in higher secondary of Islamabad provide a cooperative and work -life balance, resulting in a more desirable life for employees while teachers who have different teaching experiences have significant difference towards job satisfaction because with the passage of time employee emotionally attached with their profession as well as organization.

The results of the study are quite similar to those searched by many other psychologists and researchers like Barton GM, De Rond M and Thietart RA, Gary Dessler, Lawler, Edward E Al-Hussami M, Mishra RS and Yang H, Miao D, Zhu X, Sun Y, Liu X and Wu S $[1,2,8,9,16,17]$.

\section{Conclusion}

Mostly higher secondary schools have fixed pay system while few have variable pay system. The basic pay of the teachers contain six main components such as defense allowance (DA); house rent allowance(HRA), medical allowance, gratuity, PA and conveyance allowance and the non-cash benefits such as housing, medical, retirement benefits, day care, education reimbursement, sick leaves and vocation pay common in the compensation of teachers while cell phone, laptops, insurance, private use of official vehicle, food, loan, uniform and festival bonus were not found in the compensation of the teachers. Their salary does not link with their productivity while teachers agree that the attraction and retention of employee depend on the compensation.

When teachers feel opportunities for recognition; decision power about their work; planning of task; their contribution to productivity; and especially when teachers receive helpful suggestion and guidance from their supervisor then they will be more satisfied towards their job because the job characteristics such as variety, autonomy, and task identity and feedback system are highly correlated with each other. Similarly, the compensation practices and job satisfaction are highly correlated with each other but compensation practice in itself has no significant impact on the job satisfaction.

Male and female teacher have no significant difference as well as there is no significant difference between public and private teachers who have different qualification and age groups in higher secondary of Islamabad while teachers who have different teaching experiences have significant difference towards job satisfaction.

\section{References}

1. Barton GM (2002) Recognition at work. Scottsdale: World at Work.

2. Dessler G (2008) Human Resource Management, Prenctice Hall, America.

3. Massey, Raymond E, Gary L (1992) Bredensteiner. Compensation Packages for Farm Employees. NebGuide \#G92-1068-A. Cooperative Extension, Institute of Agriculture and Natural Resources, University of Nebraska-Lincoln.

4. Kabene SM, Orchard C, Howard JM, Soriano MA, Leduc R, et al. (2006) The importance of human resources management in health care: a global context.

5. Robbins SP (2003) Organizational Behaviour: Concepts, Controversies and Applications. (10thedn), Prentice Hall, New Jersey, USA.

6. Al-Hussami M (2008) A study of nurses job satisfaction: The relationship to organizational commitment, perceived organizational support, transactional leadership, transformational leadership and level of education, European Journal of Scientific Research 22: 286-285.

7. Pravin MM, Kabir MM (2011) Factors affecting employee job satisfaction of pharmaceutical sector. Australian journal of business and management research 9: 113-123.

8. Lawler E (1990) Strategic compensation: Aligning organizational strategies and compensation systems. Jossey-Bass San Francisco, USA.

9. Edward EL (2000) compensation Excellence: compensation strategies for the new economy. Jossey Bass, New York, USA.

10. Whittington R (1997) what is strategy and does it matter? Thomson Business Press. London, UK.

11. Gerhart B, Milkovich GT (1990) Organizational differences in managerial compensation and firm performance', Academy of Management Journal 33: 663-691.

12. De Rond M, Thietart RA (2007) Choice, chance and inevitability in strategy', Strategic Management Journal 28:535-551.

13. Trevor J (2007) Can pay be strategic? A critical exploration of strategic compensation in practice, Judge Business School, University of Cambridge, USA.

14. National Educational policy 1992-2010 Ministry of Education Pakistan

15. Daily Jung (2002) Tabish Shafi Friday

16. Mishra RS (2005) Problems of School Teacher, Common Wealth Publisher

17. Yang H, Miao D, Zhu X, Sun Y, Liu X, et al. (2008) The influence of a pay increase on job satisfaction: A study with the Chinese army, Social Behaviors and Personality 36: 1333-1340. 